JOURNAL OF SECURITY AND SUSTAINABILITY ISSUES

ISSN 2029-7017 print/ISSN 2029-7025 online

2019 September Volume 9 Number 1

http://doi.org/10.9770/jssi.2019.9.1(12)

Scopus

\title{
ESTIMATING AND MANAGING OF GOVERNMENT EXPENDITURE IN THE SELECTED EUROPEAN UNION COUNTRIES
}

\author{
Gitana Dudzevičiūtė ${ }^{1}$, Vidmantė Giedraitytè2 \\ ${ }^{1,2}$ Department of Strategic Management, General Jonas Žemaitis Military Academy of Lithuania, \\ Šilo str. 5A, LT-10322 Vilnius, Lithuania \\ E-mails: ' gitana.dudzeviciute@lka.lt; ${ }^{2}$ vidmante.giedraityte@lka.lt
}

Received 20 May 2019; accepted 30 June 2019; published 30 September 2019

\begin{abstract}
This paper has aimed to consider how government expenditure contributes to economic growth by focusing on both the level and composition of government spending, in connection to the dynamics of GDP per capita growth. The investigation covers the period from 1997 to 2017. The authors have applied total expenditure approach analyzing interrelationships between government expenditure and economic growth and division approach examining and comparing the distributions of government expenditure in the selected European Union countries. The authors have applied descriptive statistics, the Pearson's correlation, intensity rate of structural changes and Finger-Kreinin indicator. The findings have suggested the following: 1) there is no evidence on the relationship between general government expenditure and economic development in the European Union countries; 2) the countries with a greater proportion of productive spending, such as Cyprus, Greece, Lithuania, Hungary, Estonia, Slovakia have a low GDP per capita indicator. Economically strong countries, such as Denmark, France and Sweden have relatively low level of productive expenditure; 3) economically stronger countries have more stable compositions of government expenditure than economically weaker ones; 4) the countries with a similar real GDP per capita have been characterized by more similar government spending structures. As the economic gap between countries grows, divergence in allocation of government spending increases. The findings of this research could provide important guideline for the managing of government expenditure in the European Union countries. Moreover, it can serve as a guideline to a public budget management in the countries under consideration.
\end{abstract}

Keywords: correlation analysis; government expenditure; economic growth; intensity of structural changes; Finger-Kreinin indicator

Reference to this paper should be made as follows: Dudzevičiūtè, G.; Giedraityte, V. 2019. Estimating and managing of government expenditure in the European Union countries, Journal of Security and Sustainability Issues 9(1): 155-170. http://doi.org/10.9770/jssi.2019.9.1(12)

JEL classifications: $H 50, H 75, H 76, O 10, O 40$

\section{Introduction}

Scientific studies have shown that government can affect economic growth by its size and quality. The relationships among the government size and quality and economic performance have been still a subject of intensive debate among scholars and policy-makers and has reached inconclusive outcomes. The debate has focused on whether government size stimulates economic growth, whether good management is beneficial for economic performance, and how government size and management interact (Kim et al., 2018). According to Nirola and Sahu (2018), most economists agree that large governments are detrimental for economic growth. In the scientific context there are two broad approaches on government size - economic growth nexus, i.e. the Keynesian and Wagnerian approaches. The Keynesian law has stated that increased government size leads to higher aggregate demand and economic growth. The Wagnerian theory has pointed that an increase in national income requires more government expenditure (Tang 2009; Bataineh 2012; Sedrakyan, Varela-Candamio 2019). A number of recent studies have shown that many scientists (Gomez 2008; Irmen, Kuehnel, 2009; Pappa 2009; 
Abu, Abdulahi 2010; Barro, Charles 2011; Taiwo, Abayomi 2011; Ramey 2011; Anwar et al. 2012; Patricia, Izuhukwu 2013; Hajamini, Falahi 2018; Kim el al. 2018) from different countries have analyzed these issues. According to Kim et al. (2018) the investigations on government size and economic growth have revealed the importance of the state's absorption of society's resources through its spending and related taxation.

The findings of the studies have varied across the countries under consideration. The first group of the scientists has found that a larger state sector is growth-impeding (Bergh, Karlsson 2010). The second group has revealed the beneficial effect of government promoting economic development (Kneller et al., 1999). The third group of the studies have shown that increased government expenditure may slow down the total economic growth because the government may have to raise taxes or borrow money to finance rising spending (Ahmad, Loganathan, 2015).

Theory also emphasizes an optimal level of government expenditure. If government expenditure is too low, the supply of public goods is less than it needs to be to maximise economic growth. However, beyond a certain level of expenditure, the size of government sector starts negatively impact on economic growth. Moreover, if an economy experiences sub-optimal growth, this could illustrate either government size is too high or too low (Makin et al. 2019). Government expenditure management associates with allocation and use the resources responsively, efficiently and effectively. In the public expenditure management, it is advised to keep in mind the integral relationship between revenue and expenditure, particularly the allocation of the money collected in a manner that reflects most closely the public preferences (Asian development bank, 1999). Devarajan et al. (1996) presented a model that expresses the difference between

productive and non-productive government expenditures. The authors introduced how a country's desire to reach a more optimal growth rate can be achieved by increasing the proportion of productive expenditure in total government spending (Chu et al. 2018). Given the inconsistencies in empirical findings, it is surprising that relatively little attention has been paid to comparing and contrasting the government expenditure composition in EU countries at different level of economic development. We hope, that this investigation will partially fill this gap.

Problem of the research: does government size stimulates economic growth? What are the peculiarities of the government expenditure management in the selected EU countries?

Object of the research: the estimation and managing government expenditure in the European Union countries. Aim of the research: on the one hand, this research attempts to provide more reliable estimates of the interrelationship between general government spending and economic growth. On the other hand, it estimates government expenditure distribution in the EU countries.

Limitations of the research: this investigation has been bounded by the relationship between general government expenditure and economic growth, also the breakdowns of government expenditure on the basis of the activities they support. In this paper, the authors have not estimated the causal nexus between government expenditure and economic growth and the effect of the government expenditure's allocation by activities on economic performance. It is the main limitations of the research. Despite the limitations, we believe that the research reveals the key findings in the EU countries.

In the introduction, the authors have presented theoretical background, scientific problem and the aim of the investigation. Section 2 reviews previous studies on the estimation and management of the government expenditure and research methodology. The studies of different countries are summarized and the main insights are provided. Section 3 estimates relationships between indicators and assesses distributions of the government expenditure. Finally, the last section summarizes the main insights. 


\section{Empirical evidence and research methodology}

\subsection{The overview of recent studies}

The effect of government size on economic growth has been a controversial issue. On the one hand, government can provide public health and education, infrastructure and security and other activities for the whole community. On the other hand, government cannot allocate very large sums to expenditure given the need to finance spending by taxes and borrowing. Government can play both a positive and negative role in economic development (Hajamini, Falahi 2018). Governments tend to absorb a sizeable share of the national output and thereby affect the economic growth (Nirola and Sahu 2018). According to Makin et al. (2019), before the First World War, government expenditure in industrial economies made approximately ten per cent of national income.

In the twentieth century, the relative size of the government sector started to grow significantly, especially in the 1960's and 1970s due to significant increase in spending on health, education and age pensions. During the global financial crisis in 2008-2009, the share of government expenditure rose when governments implemented the Keynesian fiscal policy in order to stabilise aggregate demand. For the advanced economies this share has since fallen on average five percent of GDP (Makin et al. 2019). In addition, the studies (North 1990; Fraj et al. 2018) carried out have supported the importance of public management in sustaining economic growth. Management corresponds to the effectiveness to develop institutions able to organize markets, involving effective regulation that promotes competition, the creation and protection of property rights, fight against corruption, and sound macroeconomic policy (Fraj et al. 2018). Public expenditure management is country-specific. It should be grounded on the economic, social, administrative, and implementation capacity of the specific country. The allocation of funds results from a series of forces that, theoretically, have developed a certain intuition about what public needs (Asian Development Bank 1999). Hereafter, the findings from the most recent relevant investigations have been revealed.

Taiwo and Abayomi (2011) studied the effects of government expenditure on the economic growth in Nigeria over 1970-2008. The results have indicated a positive relationship between real GDP growth and capital expenditure. The researchers have noticed that government should promote efficiency in the allocation of resources. Wang and Wen (2013) analyzed the macroeconomic effect of government spending in China. The results have shown that government expenditure Granger-causes output and investment, and inflation as well.

Morozumi and Veiga (2016) examined the role of institutions in the relationship between public spending and economic growth. Empirical results based on a dataset of 80 countries over the period of 1970-2010 have suggested that when institutions promote government to be accountable to the public, public capital spending stimulates economic growth. The study has shown that growth-promoting effect prevails for various financing sources including an increase in budget deficit and revenue, also a reallocation from current spending. Asimakopoulos and Karavias (2016) studied the nature of the relationship between government size and economic growth and identified the optimal level of government size. They have revealed that this relationship is statistically significant above and below the optimal level, even after splitting the sample to developed and developing countries. Finally, the authors have found an asymmetric impact of government size on economic growth in both developed and developing countries. Mladenovic et al. (2016) analysed the influence of health care expenditures on the GDP growth rate. The results have shown that the total health care expenditure has the highest influence on the economic growth rate forecasting. The researchers have concluded, that the improvements in health status would be worth the effort even if they turn out to have little impacts on growth.

Wu et al. (2017) explored the impacts of government expenditures and corruption on total factor productivity using provincial panel data from 2007 to 2014 in China. The results have suggested that "U" shape curve relationships exist between government expenditures of administrative service, safeguard governance, investment development and total factor productivity. Moreover, the findings have illustrated that increased corruption levels can directly reduce regional total factor productivity. Also, increasing the shares of government expenditures could improve the total factor productivity up until the threshold value. 
Nirola and Sahu (2018) investigated the impact of government size on economic growth across 23 states in India from 2005 to 2014 for varying degrees of institutions' quality. The authors have found that state governments should emphasize on quality of institutions to enhance state-level economic growth. In the context of increase in government size, the states that have better quality of institutions show a lower negative impact on economic growth compared to less progressive states. Dudzevičiūtè et al. (2018) studied causal nexus between government expenditure and economic development in the European Union countries over 1995-2015. The research has confirmed the causality running from government expenditure to economic growth in Sweden and Slovakia. In this case, the government should focus on expenditure as a factor of economic growth. Moreover, unidirectional causality from economic growth to government expenditure has been detected in France, Belgium, Germany, Portugal and Cyprus. This has indicated that the government should ensure that resources are properly managed and efficiently allocated to stimulate economic development. In addition, the results have revealed the absence of causality between the variables in Poland. The study of Hajamini and Falahi (2018) examined the non-linear relationship between government size and economic growth among 14 developed European countries during 1995-2014. The results have indicated an asymmetric effect of final consumption expenditure and government gross fixed capital formation on economic growth when they are above and below the optimal level. The optimum values have been estimated to be 16.63 and $2.31 \%$, respectively. Moreover, it has been revealed that current expenditure other than final consumption always has a negative effect on economic growth. The researchers have concluded, that in terms of policy implementation, governments of developed countries should be aware that misallocation of public expenditure can become unproductive after passing an optimal size. Kim et al. (2018) explored whether there exist nonlinear threshold effects of government size and governance on growth and whether the effect is mainly mediated through the productivity growth channel in developed and developing countries. The scientists have found that better governance helps government increase productivity and growth, and bigger government size helps governance raise productivity. In addition, government size turns harmful to growth above some threshold level and governance becomes beneficial to growth above some threshold level of governance. Facchini and Seghezza (2018) focused on the effects of the composition of public spending on growth in France for the period 1870-2010. The authors have revealed that the expenditure which is aimed at the protection of property rights contributes to output growth. Also, in the area of social expenditure, only health spending contributes to economic growth. Moreover, public interventions in support of the economy have no impact on growth. Finally, the research has confirmed that the restriction of the size of the government and the delimitation to its essential functions tends to favour output growth (Facchini, Seghezza 2018). Chu et al. (2018) examined the relationship between the compositions of government expenditure and economic growth. They used panel data from 37 high-income and 22 low to middle-income countries covering 1993-2012. The study has shown that a shift in government expenditure away from non-productive towards productive forms of spending are associated with higher levels of growth in both high-income and low to middle-income countries. Moreover, the authors have found that an increase in level of government expenditure has a crowding-out effect and thus negatively impacts on long-run economic growth.

Sedrakyan and Varela-Candamio (2019) analyzed the causal relationship between government expenditure and economic growth in Armenia and Spain for the period of 1996 - 2014. The findings have provided a strong evidence of Wagner's law in both countries. In the period of economic growth, it has been a strong public policy management tool. In addition, the Keynesian law has played an important role in both countries during the periods of economic decline or high public debt. Makin et al. (2019) paid attention to the influence of the relative size of government on economic growth in Australia. The findings have suggested that the share of government expenditure in Australia consistent with maximising economic growth amounted to 31 per cent of national income, i.e. significantly below the current level.

To sum up, the studies have revealed that in many cases the relationship between government expenditure and economic growth has been detected, but the practices of different countries lead to different findings. The studies have illustrated when government expenditure is too low, the supply of public goods is less than it needs to be to maximise economic growth. However, beyond a certain level of expenditure, the size of government sector starts negatively impact on economic growth rates. Moreover, public expenditure management is also countryspecific, depending on the country's economic, social, administrative, and implementation opportunities. 


\subsection{Research data and methodology}

Data. The research has been based on Eurostat information. Eurostat has collected annual data on government expenditure by function. Data are available at two levels. The first level splits expenditure into ten classes according to functions, and the second level further splits the first level classes into further groups (OECD 2014). The investigation covers the period from 1997 to 2017. For the estimations, some variables have been used that is real GDP per capita growth (percentage), government expenditure as a share of GDP (percentage), government expenditure by functions (percentage of total expenditure).

Methodology. The authors have referred to methodology considered in studies of different authors (Memedovic, Iapadre 2010; Cortuk, Singh 2010; Zhu, Wang 2011; OECD 2014; Pavelescu 2014; Mahmood, Linden 2017). The indicators for estimation of government expenditure patterns (intensity of structural changes and FingerKreinin) have been employed. The investigation consists of some stages as follows:

Stage 1. There have been used descriptive statistics analysis, which has allowed assessing the dynamics of general government expenditure and economic performance. The EU countries have been grouped into four categories, such as high spenders, upper middle spenders, and lower middle and low spenders. Linkage analysis between groups has shown the main differences of the EU countries. For further investigation, the authors have selected twelve countries (France, Denmark, Sweden, Greece, Hungary, Italy, Poland Czechia, Slovakia, Cyprus, Estonia, Lithuania), i.e. three countries from each group.

Stage 2. Correlation analysis has been applied. Taking into consideration Jarque-Bera (1987) statistics confirming the normal distribution of the variables, the authors have used the Pearson's correlation. Null hypothesis and alternative hypothesis have been checked: null hypothesis: normal distribution; and alternative hypothesis: not normal distribution. If probability value is $\leq 5 \%$, null hypothesis should be rejected and accepted alternative hypothesis. Conversely, the null hypothesis is accepted if probability value is $>5 \%$.

Stage 3. The calculation of the intensity rate of structural changes. This indicator shows the shift of the pattern in time $t_{i}$ compare with the basic period. The higher indicator reveals more intensive structural changes of the government expenditure's pattern analyzed, and conversely. The intensity rate is calculated as follows:

$$
\text { CISC }=\sqrt{\sum_{i=1}^{r}\left(g_{i 1}-g_{i 0}\right)^{2}}
$$

Where: $\mathrm{r}$ - number of considered government expenditure by economic function, $\mathrm{g}_{\mathrm{i} 1}, \mathrm{~g}_{\mathrm{i} 0}$ - the weight of government expenditure by function $\mathrm{i}$ in the analyzed period in year 1 and year 0 , respectively.

Stage 4. Estimation of dissimilarities of the expenditure patterns across the countries. Finger-Kreinin dissimilarity indicator (D) measures how much a given distribution differs from a chosen. It is calculated as follows:

$$
D=\frac{1}{2} \sum_{i=1}^{n}\left|a_{i}-b_{i}\right|
$$

where: $a_{i}$ and $b_{i}$ show the share of expenditure by function $i$ in each of the two distributions. $D$ index ranges between zero, denoting equality and one, showing maximum dissimilarity.

Next section has described the government expenditure trends. 


\section{The investigation of the government expenditure trends in EU countries}

\subsection{The relationships between government expenditure and GDP per capita}

Government expenditure in the context of economic performance. In this section, the authors have analyzed the main tendencies of government expenditure and economic growth in the EU countries. The period involves the years from 1997 to 2017. The EU countries have been grouped into four categories, such as high spenders, upper middle spenders, and lower middle and low spenders (Table 1).

Table 1. Government expenditure and GDP per capita in the EU countries

\begin{tabular}{|c|c|c|c|c|c|}
\hline \multirow[b]{2}{*}{$\begin{array}{l}\text { Groups of countries } \\
\text { by government } \\
\text { expenditure }\end{array}$} & \multicolumn{2}{|c|}{ Average, 1997-2017 } & \multirow[b]{2}{*}{$\begin{array}{l}\text { Groups of countries } \\
\text { by government } \\
\text { expenditure }\end{array}$} & \multicolumn{2}{|c|}{ Average, 1997-2017 } \\
\hline & $\begin{array}{c}\text { Government } \\
\text { expenditure as } \\
\text { percentage of GDP }\end{array}$ & $\begin{array}{l}\text { GDP per } \\
\text { capita, Euro }\end{array}$ & & $\begin{array}{c}\text { Government } \\
\text { expenditure as } \\
\text { percentage of GDP }\end{array}$ & $\begin{array}{c}\text { GDP per } \\
\text { capita, Euro }\end{array}$ \\
\hline High spenders & & & Poland & 43.8 & 8452 \\
\hline France & 54.6 & 30205 & Czechia & 42.5 & 13814 \\
\hline Denmark & 53.8 & 43743 & Slovakia & 42.4 & 11014 \\
\hline Sweden & 52.3 & 37629 & Luxembourg & 41.7 & 75476 \\
\hline Finland & 52.3 & 33329 & Spain & 41.7 & 22586 \\
\hline Belgium & 51.7 & 32319 & Malta & 41.2 & 16133 \\
\hline Austria & 51.4 & 34138 & United Kingdom & 41.0 & 29229 \\
\hline Upper middle spenders & & & Low spenders & & \\
\hline Greece & 49.3 & 18857 & Cyprus & 38.9 & 21695 \\
\hline Hungary & 49.1 & 9576 & Estonia & 37.8 & 10848 \\
\hline Italy & 48.6 & 26895 & Lithuania & 37.7 & 8490 \\
\hline Croatia & 47.5 & 9895 & Latvia & 37.5 & 8181 \\
\hline Slovenia & 47.0 & 16471 & Bulgaria & 37.4 & 4481 \\
\hline Portugal & 46.3 & 16443 & Ireland & 36.8 & 38671 \\
\hline Germany & 45.6 & 31271 & Romania & 36.2 & 6225 \\
\hline Lower middle spenders & & & & & \\
\hline Netherlands & 44.4 & 37081 & & & \\
\hline
\end{tabular}

Source: authors' calculations based on Eurostat data (2017a,b).

Using linkage analysis between groups, some interesting tendencies have been revealed. Referring to the average data, the indicators of government expenditure as a percentage of GDP and real GDP per capita have varied across the countries. It is noticed that different countries demonstrate various results of associations between government expenditure and economic performance. There are economically strong countries that are high and upper middle spenders (France, Scandinavian countries, Belgium, Austria, Germany) and economically strong countries that are low and lower middle spenders (the Netherlands, Ireland, United Kingdom, Luxembourg) as well as there are economically weak countries which spend a lot (Greece, Hungary, Croatia, Slovenia, Portugal) and countries which are economically weak with lower middle or low expenditure (Lithuania, Latvia, Estonia, Bulgaria, Romania, Poland, Slovakia). Therefore, there is no evidence on the relationship between government expenditure and economic development. We cannot state that the countries which spend a lot have higher GDP per capita indicator than those which spend less or vice versa.

For further investigation, the authors have selected twelve countries (France, Denmark, Sweden, Greece, Hungary, Italy, Poland Czechia, Slovakia, Cyprus, Estonia, Lithuania), i.e. three countries from each group.

Jarque-Bera statistics. Before applying the Pearson's correlation, the authors have to confirm the normal distribution of the variables. For this purpose, we have used Jarque-Bera statistics (Annex A). All calculations 
have been based on Eviews v. 8.0. Results have shown that not all variables are normally distributed. Therefore, we have employed the data conversion into log. After that, in many cases the variables have become normally distributed, except the cases of Hungary, Czechia, Estonia and Lithuania.

Correlation analysis. The results of correlation analysis across the selected EU countries have been presented in Table 2.

Table 2. The Pearson's correlation between government expenditure and economic growth

\begin{tabular}{|c|c|c|c|}
\hline Countries & Correlation coefficient, $r$ & t-statistic & Probability \\
\hline France & -0.3260 & -1.3800 & 0.1866 \\
\hline Denmark & -0.0310 & -0.1240 & 0.9028 \\
\hline Sweden & 0.2942 & 1.2312 & 0.2360 \\
\hline Greece & -0.7635 & -5.1534 & 0.0001 \\
\hline Italy & -0.1099 & -0.3830 & 0.7084 \\
\hline Poland & 0.0665 & 0.2904 & 0.7747 \\
\hline Slovakia & -0.4752 & -2.3542 & 0.0295 \\
\hline Cyprus & -0.6496 & -3.7247 & 0.0014 \\
\hline
\end{tabular}

Source: authors' calculations based on Eviews v. 8.0.

Note: the level of significance is $5 \%$

As Table 2 has shown, negative and statistically significant relationships between government expenditure and economic growth have been detected in three countries, such as Greece, Slovakia and Cyprus. It has informed about two possible scenarios. Firstly, as the government expenditure increases, GDP per capita growth rate decreases. Secondly, as the economy grows, government spending tends to decline. Moreover, negative correlation between government expenditure and economic growth could signal the inefficiency of the expenditure management. Other countries under consideration have demonstrated statistically insignificant relations. It has been noticed, that the policy-makers should be more focused on determining the optimal level of government expenditure to boost economic growth.

Next section focuses on the structures of government spending.

\subsection{Managing of government expenditure}

This section attempts to answer three questions: (a) what are the policy directions under which government expenditure contributes to economic growth? (b) what are the government spending components that have a stronger impact on growth? and (c) what are the intensity of structural changes and dissimilarities of government patterns across the selected EU countries?

Productive and non-productive spending. Referring to the studies of Park (2006), Christie (2012) and Chu et al. (2018), we have classified general government expenditure into productive and non-productive. Productive government expenditure affects private sector productivity and hence has a direct impact on economic growth. Non-productive spending, which has an influence on citizens' welfare, is likely to have a zero or negative growth impact (Kneller et al. 1999; Chu et al. 2018). Productive government expenditure is a sum of spending on health, education, economic affairs, defence, housing, and general public services, meanwhile, nonproductive government expenditure consists of social security, recreation, culture and religion spending (Chu et al. 2018). 
Table 3. Average data over 1997-2017

\begin{tabular}{|c|c|c|c|}
\hline Countries & $\begin{array}{c}\text { Productive government } \\
\text { expenditure, } \%\end{array}$ & $\begin{array}{c}\text { Non-productive government } \\
\text { expenditure, } \%\end{array}$ & GDP per capita, Euro \\
\hline France & 52.0 & 48.0 & 30205 \\
\hline Denmark & 50.8 & 49.2 & 43743 \\
\hline Sweden & 53.7 & 46.3 & 37629 \\
\hline Greece & 60.4 & 39.6 & 18857 \\
\hline Hungary & 58.5 & 41.5 & 9576 \\
\hline Italy & 54.2 & 45.8 & 26895 \\
\hline Poland & 52.6 & 47.4 & 13814 \\
\hline Czechia & 60.5 & 39.5 & 11014 \\
\hline Slovakia & 55.6 & 44.4 & 21695 \\
\hline Cyprus & 64.2 & 35.8 & 10848 \\
\hline Estonia & 56.4 & 43.6 & 8490 \\
\hline Lithuania & 60.1 & 39.9 & \\
\hline
\end{tabular}

Source: authors' calculations based on Eurostat data (2017a,b)

As the analysis of government expenditure has shown, on the one hand, the countries with a greater proportion of productive spending (Cyprus, Greece, Lithuania, Hungary, Estonia, Slovakia) have a low GDP per capita indicator. On the other hand, economically strong countries (Denmark, France and Sweden) have relatively low level of productive expenditure. In this case we can assume, that diverting expenditure from productive to non-productive can promote economic development. However, the conclusions should be taken with caution as we have analyzed only the cases of twelve countries.

Government expenditure by function and intensity rate of structural changes. shows the kind of the spending which dominates in the structure of general government expenditure in the countries under consideration. It is noticed that all countries spend most on social protection involving spending on sickness and disability, old age, survivors, family and children, unemployment and others. Next, spending on health (medical products, appliances and equipment, outpatient services, hospital services and others) prevails in France, Denmark, Sweden, Czechia, Slovakia and Lithuania. Spending on education (pre-primary and primary education, secondary and tertiary education and others) takes a grate share in Poland and Estonia. Spending on general public services (financial and fiscal affairs, external affairs, foreign economic aid, general services, public debt transactions and others) dominates in Greece, Hungary, Italy and Cyprus. Hereafter, we will answer the question of which government spending structures have been the most stable and dynamic. It shows intensity rate of structural changes.

Table 4. Intensity rate (percentage points) of government expenditure, 2017 comparison with 1997

\begin{tabular}{|c|c|c|c|c|c|c|c|c|c|c|c|c|}
\hline Country / Activity & $F R$ & $D K$ & $S E$ & $E L$ & $H U$ & $I T$ & $P L$ & $C Z$ & $S K$ & $C Y$ & $E E$ & $L T$ \\
\hline General public services & 5.6 & 5.7 & 5.1 & 13.1 & 8.4 & 8.9 & 6.5 & 1.0 & 0.6 & 1.9 & 1.1 & 24.4 \\
\hline Defence & 1.3 & 0.6 & 1.5 & 1.0 & 0.7 & 0.3 & 0.7 & 2.1 & 0.6 & 2.7 & 1.7 & 2.1 \\
\hline Public order and safety & 0.3 & 0.2 & 0.4 & 2.4 & 1.5 & 0.2 & 0.3 & 0.1 & 1.9 & 0.8 & 2.4 & 0.2 \\
\hline Economic affairs & 1.2 & 0.5 & 1.2 & 4.6 & 4.7 & 0.7 & 3.1 & 4.1 & 9.7 & 4.9 & 0.2 & 4.3 \\
\hline Environment protection & 0.5 & 0.2 & 0.3 & 2.0 & 0.4 & 0.5 & 0.3 & 0.4 & 0.8 & 0.2 & 0.1 & 1.0 \\
\hline Housing and community amenities & 0.1 & 0.7 & 1.8 & 0.4 & 0.8 & 0.4 & 1.9 & 1.4 & 0.2 & 1.4 & 0.5 & 0.0 \\
\hline Health & 1.2 & 4.7 & 3.8 & 0.1 & 0.4 & 3.0 & 4.8 & 3.7 & 5.6 & 0.0 & 1.1 & 8.0 \\
\hline Recreation, culture and religion & 0.7 & 0.5 & 0.8 & 0.3 & 4.9 & 0.1 & 1.2 & 0.2 & 0.3 & 0.0 & 0.4 & 0.9 \\
\hline Education & 0.8 & 1.2 & 1.9 & 0.8 & 0.1 & 1.3 & 0.7 & 0.9 & 2.3 & 0.1 & 3.9 & 4.6 \\
\hline Social protection & 3.8 & 1.0 & 1.6 & 13.3 & 0.4 & 8.0 & 1.1 & 2.2 & 6.1 & 11.7 & 4.9 & 12.5 \\
\hline Total & 15.5 & 15.3 & 18.4 & 38.0 & 22.3 & 23.4 & 20.6 & 16.1 & 28.1 & 23.7 & 16.3 & 58.0 \\
\hline
\end{tabular}


As the table above reports, 2017 compare with 1997, Lithuania and Greece have the most intensive structures of government expenditure. Denmark and France report the most stable compositions of government spending. On the basis of the relationship between intensity rate of structural changes and GDP per capita, we note that economically stronger countries have more stable compositions of government expenditure than economically weaker countries. For example, the average annual structural changes in government spending in Lithuania have been 3.8 times more intensive than in Denmark and France. The high rate of structural changes shows that the government is facing challenges every year when planning a budget. This could signal the absence of a unified policy.

Assessing of the government expenditure patterns'dissimilarity. In order to assess the dissimilarity of the structures of government expenditure across the countries, Finger-Kreinin indicator has been applied. This indicator has summarized how much a given distribution of government expenditure differs from other country. Finger-Kreinin ranges between 0 and 1 or 0 and $100 \%$. When value is equal to 0 , this means that the structures of pair of countries being considered are identical; and when it is equal to 1 or 100\%, this means maximum dissimilarity. Table 5 gives the Finger-Kreinin of government expenditure patterns for all pairings for the period from 1997 to 2017.

Table 5. Finger-Kreinin indicator of government expenditure patterns over 1997 - 2017 (average data)

\begin{tabular}{|c|c|c|c|c|c|c|c|c|c|c|c|c|}
\hline Country & $F R$ & $D K$ & $S E$ & $E L$ & $H U$ & $I T$ & $P L$ & $C Z$ & $S K$ & $C Y$ & $E E$ & $L T$ \\
\hline FR & 0 & 6.5 & 4.7 & 14.6 & 13.8 & 7.0 & 6.9 & 15.3 & 10.0 & 21.1 & 16.8 & 11.5 \\
\hline DK & 6.5 & 0 & 5.3 & 18.6 & 16.5 & 10.4 & 11.0 & 19.0 & 13.6 & 23.7 & 19.6 & 13.9 \\
\hline SE & 4.7 & 5.3 & 0 & 15.1 & 13.6 & 7.9 & 7.4 & 18.5 & 12.8 & 18.8 & 17.1 & 12.8 \\
\hline EL & 14.6 & 18.6 & 15.1 & 0 & 8.9 & 9.7 & 14.6 & 19.2 & 11.7 & 14.9 & 17.6 & 14.1 \\
\hline HU & 13.8 & 6.5 & 13.6 & 8.9 & 0 & 9.8 & 11.2 & 12.8 & 9.2 & 12.6 & 14.2 & 11.1 \\
\hline IT & 7.0 & 10.4 & 7.9 & 9.7 & 9.8 & 0 & 9.8 & 17.7 & 9.1 & 18.3 & 18.9 & 13.8 \\
\hline PL & 6.9 & 11.0 & 7.4 & 14.6 & 11.2 & 9.8 & 0 & 15.0 & 10.7 & 14.6 & 12.9 & 9.2 \\
\hline CZ & 15.3 & 19.0 & 18.5 & 19.2 & 12.8 & 17.7 & 15.0 & 0 & 10.0 & 20.2 & 11.8 & 10.1 \\
\hline SK & 10.0 & 13.6 & 12.8 & 11.7 & 9.2 & 9.1 & 10.7 & 10.0 & 0 & 19.8 & 13.6 & 8.0 \\
\hline CY & 21.1 & 23.7 & 18.8 & 14.9 & 12.6 & 18.3 & 14.6 & 20.2 & 19.8 & 0 & 16.1 & 13.2 \\
\hline EE & 16.8 & 19.6 & 17.1 & 17.6 & 14.2 & 18.9 & 12.9 & 11.8 & 13.6 & 16.1 & 0 & 6.9 \\
\hline LT & 11.5 & 13.9 & 12.8 & 14.1 & 11.1 & 13.8 & 9.2 & 10.1 & 8.0 & 13.2 & 6.9 & 0 \\
\hline
\end{tabular}

Source: Authors' calculations based on Eurostat data (2017a)

According to the average values of Finger-Kreinin in the period of 1997 - 2017, some sightings can be identified. Finger-Kreinin indicator has varied in the interval of $4.7 \%-23.7 \%$. Assessing the pairs of the countries, the most significant dissimilarity has been revealed between the government expenditure structures of Denmark and Cyprus (23.7\%), France and Cyprus (21.1\%) and Czechia and Cyprus (20.2\%). Moreover, the analysis has suggested that Sweden and France, Sweden and Denmark as well as Denmark and France have the lowest rate of dissimilarity in distribution of government expenditure. It makes $4.7 \%, 5.3 \%$ and $6.5 \%$ respectively. Finally, it could be noted, that countries with a similar level of economic development (similar real GDP per capita) have also been characterized by more similar government spending structures. As the economic gap between countries grows, divergence in allocation of government spending increases.

Next section provides the main insights comparing the research results with previous studies.

\subsection{Discussion of the research results}

As previously mentioned, scientific studies have shown that government can affect economic growth by its size and quality. The relationships among the government size and quality and economic performance have been still a subject of intensive debate among scholars and policy-makers and has reached inconclusive outcomes. The findings of the studies have varied across the countries. The first group of the scientists has found that a larger state sector is growth-impeding (Bergh, Karlsson 2010). The second group has revealed the beneficial 
effect of government promoting economic development (Kneller et al., 1999). The third group of the studies have shown that increased government expenditure may slow down the total economic growth because the government may have to raise taxes or borrow money to finance rising spending (Ahmad, Loganathan, 2015).

This research has shown no evidence on the relationship between government expenditure and economic development. We cannot state that the countries which spend a lot have higher GDP per capita indicator than those which spend less or vice versa. Moreover, three out of eight selected countries, such as Greece, Slovakia and Cyprus have demonstrated a negative and statistically significant relationships between government expenditure and economic growth. In the remaining countries, statistically insignificant relations have been found. The results have supported the approach that a larger governmental sector is growth-impeding and increased government expenditure may slow down the total economic growth. According to Devarajan et al. (1996), a country's desire to reach a more optimal growth rate can be achieved by increasing the proportion of productive expenditure in total government spending. Later, this insight has been partly supported by Chu et al. (2018) examining the relationship between the compositions of government expenditure and economic growth. On the one hand, the study has shown that a shift in government expenditure away from non-productive towards productive spending are associated with higher levels of growth, however, on the other hand, an increase in level of government expenditure has a crowding-out effect and thus negatively impacts on long-run economic growth.

The results of our research have shown that the countries with a greater proportion of productive spending (Cyprus, Greece, Lithuania, Hungary, Estonia, Slovakia) have a relatively low GDP per capita indicator. Economically strong countries, such as Denmark, France and Sweden have relatively low level of productive expenditure. Moreover, economically stronger countries have more stable compositions of government expenditure than economically weaker countries. Finally, it could be noted, that countries with a similar real GDP per capita have been characterized by more similar government spending structures.

\section{Conclusions}

This research, on the one hand, has provided more reliable estimates of the interrelationship between general government spending and economic growth. On the other hand, it estimates government expenditure distribution in the EU countries. The scientific studies have shown that the effect of government size on economic growth has been a controversial issue. Government can play both a positive and negative role in economic development.

The analysis has shown, that there is no evidence on the relationship between general government expenditure and economic development in the European Union countries. We cannot say that the countries which spend a lot have higher GDP per capita indicator than those which spend less or vice versa.

Negative and statistically significant relationships between government expenditure and economic growth have been detected in three out of eight countries, such as Greece, Slovakia and Cyprus. It could signal the inefficiency of the government expenditure management. Other countries under consideration have demonstrated statistically insignificant relations. It has been noticed, that the policy-makers should be more focused on determining the optimal level of government expenditure to boost economic growth. Moreover, the results have revealed, that the countries with a greater proportion of productive spending, such as Cyprus, Greece, Lithuania, Hungary, Estonia, Slovakia have a low GDP per capita indicator.

Economically strong countries, such as Denmark, France and Sweden have relatively low level of productive expenditure. In this case we can assume, that diverting expenditure from productive to non-productive can promote economic development. However, the conclusions should be taken with caution as we have analyzed only the cases of twelve countries. It is noticed, that all countries spend most on social protection. Next, spending on health prevails in France, Denmark, Sweden, Czechia, Slovakia and Lithuania. Spending on education takes a grate share in Poland and Estonia. Spending on general public services dominates in Greece, Hungary, Italy and Cyprus.

Also, economically stronger countries have more stable compositions of government expenditure than economically weaker ones. 
In the economically weaker countries, the intensive rate of structural changes shows that the government is facing challenges every year when planning a budget. This could signal the absence of a unified policy. Moreover, the countries with a similar real GDP per capita have been characterized by more similar government spending structures. As the economic gap between countries grows, divergence in allocation of government spending increases. The research has provided the following guidelines for the policy makers: 1) to focus on determining the optimal level of government expenditure to boost economic growth in the EU countries; 2) to focus on budget planning and unified policy which stimulates economic development; 3) to focus on increasing efficiency of the allocation government expenditure.

\section{References}

Abu, N., Abdulahi, U. 2010. Government expenditure and economic growth in Nigeria, 1970-2008: a disaggregated analysis. Business and Economic Journal 4 (3): 237-330.

Ahmad, U. G., Loganathan, N. 2015. The causal nexus between government expenditure and economic growth in Nigeria: evidence from a bootstrap rolling window approach. The American Journal of Innovative Research and Applied Sciences 2(1): 16-24.

Anwar, M.A., Rafique, Z., Joiya, S.A. 2012.Defense spending-economic growth nexus: a case study of Pakistan. Pakistan Economicand Social Review 50 (2): 163-182.

Asian Development Bank. 1999. Managing government expenditure. Available on the Internet: https://www.adb.org/publications/managing-government-expenditure.

Asimakopoulos, S., Karavias, Y. 2016. The impact of government size on economic growth: A threshold analysis, Economics Letters 139: 65-68. Available on the Internet: http://dx.doi.org/10.1016/j.econlet.2015.12.010.

Barro, Robert J., Charles J. R. 2011. Macroeconomic effects from government purchases and taxes. Quarterly Journal of economics 126(1): 51-102.

Bataineh, I. M. 2012. The impact of government expenditures on economic growth in Jordan, Interdisciplinary Journal of Contemporary Research in Business 4 (6): 1320-1338.

Bergh, A., Karlsson, M. 2010. Government size and growth: accounting for economic freedom and globalization, Public Choice 42: $195-213$.

Christie, T. 2012. The effect of government spending on economic growth: testing the non-linear hypothesis, Bulletin of Economic Research 66 (2):183-204.

Chu, T. T., Holscher, J., McCarthy, D. 2018. The impact of productive and non-productive government expenditure on economic growth: an empirical analysis in high-income versus low- to middle-income economies, Empirical Economics. Available on the Internet: https://doi.org/10.1007/s00181-018-1616-3.

Cortuk, O., Singh, N. 2010. Structural changes and growth in India. Economics Letters 2: 178-181.

Devarajan, S., Swaroop V., Zou, H. 1996. The composition of public expenditure and economic growth, Journal of Monetary Economics 37 (2): 313-344.

Dudzevičiūtè, G., Šimelytė, A., Liučvaitienè, A. (2018). Government expenditure and economic growth in the European Union countries, International Journal of Social Economic 45 (2): 372-386. https://doi.org/10.1108/IJSE-12-2016-0365

Eurostat database (general government expenditure by function). 2017a. Available on the internet: http://ec.europa.eu/eurostat/data/ database.

Eurostat database (real GDP per capita). 2017b. Available on the internet: https://ec.europa.eu/eurostat/tgm/table.do?tab=table\&init=1 \&language $=$ en $\&$ p code $=$ sdg_08_10\&plugin $=1$.

Facchini, F., Seghezza, E. 2018. Public spending structure, minimal state and economic growth in France (1870-2010), Economic Modelling 72: 151-164. Available on the Internet: https://doi.org/10.1016/j.econmod.2018.01.014.

Fraj, S. H., Hamdaoui, M., Maktouf, S. 2018. Governance and economic growth: the role of the exchange rate regime, International Economics 156: 326-364. Available on the Internet: https://doi.org/10.1016/j.inteco.2018.05.003.

Gomez, M.A. 2008. Fiscal policy, congestion, and endogenous growth, Journal of Public Economic Theory 10: 595-622. 
Hajamini, M., Falahi, A. M. 2018. Economic growth and government size in developed European countries: a panel threshold approach, Economic Analysis and Policy 58: 1-13. Available on the Internet: https://doi.org/10.1016/j.eap.2017.12.002

Irmen, A., Kuehnel, J. 2009. Productive government expenditure and economic growth, Journal of Economic Surveys 23 (4): $692-733$.

Jarque, C. M., Bera, A. K. 1987. A test for normality of observations and regression residuals, International Statistical Review 55: 163-172. Available on the Internet: http://academicos.fciencias.unam.mx/wp-content/uploads/sites/91/2015/04/jarque_bera_87.pdf

Kim, D-H., Wub, Y-CH., Linc, SH-CH. 2018. Heterogeneity in the effects of government size and governance on economic growth, Economic Modelling 68: 205-216. Available on the Internet: http://dx.doi.org/10.1016/j.econmod.2017.07.014

Kneller, R., Bleaney, M., Gemmell, N. 1999. Fiscal policy and growth: evidence from OECD countries, Journal of Public Economics 74 (2): 171-190.

Mahmood, T., Linden, M. (2017). Structural change and economic growth in Schengen region, International Journal of Economics and Financial Issues 7 (1): 303-311

Makin, A. J., Pearce, J., Ratnasiri, S. 2019. The optimal size of government in Australia, Economic Analysis and Policy 62: 27-36. Available on the Internet: https://doi.org/10.1016/j.eap.2018.12.001

Memedovic, O; Iapadre, L. 2010. Structural change in the world economy: main features and trends. UNIDO, Working Paper (24).

Mladenovic, I., Milovancevic, M., Mladenovic, S. S., Marjanovic, V., Petkovic, B. 2016. Analyzing and management of health care expenditure and gross domestic product (GDP) growth rate by adaptive neuro-fuzzy technique, Computers in Human Behavior 64: 524530. Available on the Internet: http://dx.doi.org/10.1016/j.chb.2016.07.052

Morozumi, A., Veiga, F. 2016. Public spending and growth: the role of government accountability, European Economic Review 89: 148171. Available on the Internet: http://dx.doi.org/10.1016/j.euroecorev.2016.07.001

Nirola, N., Sahu, S. 2018. The interactive impact of government size and quality of institutions on economic growth- evidence from the states of India, Heliyon 5: e01352. http://10.1016/j.heliyon.2019.e01352

North, D., 1990. A transaction cost theory of politics. Journal of Theoretical Politics 2 (4): 355-367.

OECD. 2014. National accounts at a glance, OECD Publishing. Available on the Internet: http://dx.doi.org/10.1787/na_glance-2014-en.

Pappa, E. 2009. The effects of fiscal shocks on employment and the real wage, International Economic Review 50: 400-421.

Park, H. 2006. Expenditure composition and distortionary tax for equitable economic growth, IMF Working Papers 06 (165).

Patricia, C. N., Izuhukwu, C. D. 2013. Impact of government expenditure on economic growth in Nigeria, International Journal of Business and Management Review 1(4): 64-71.

Pavelescu, F. M. 214. Methodological consideration on the size of coefficient of intensity of structural changes (CISC). Available on the Internet: http://www.revistadestatistica.ro/wp-content/uploads/2014/07/RRS_2_2014_a09.pdf

Ramey, Valerie A. 2011. Can government purchases stimulate the economy? Journal of Economic Literature 49(3): 673-85.

Sedrakyan, G. S., Varela-Candamio, L. 2019. Wagner's law vs. Keynes' hypothesis in very different countries (Armenia and Spain), Journal of Policy Modeling. Available on the Internet: https://doi.org/10.1016/j.jpolmod.2019.02.011

Taiwo, M., Abayomi, T. 2011. Government expenditure and economic development: empirical evidence from Nigeria, MPRA Paper No 37293. Available on the Internet: https://mpra.ub.uni-muenchen.de/37293/

Tang, T. C. 2009. Wagner's law versus Keynesian hypothesis in Malaysia: an impressionistic view, Discussion Paper 21/09. ISSN $1441-5429$.

Wu, Sh., Li, B., Nie, Q., Chen, Ch. 2017. Government expenditure, corruption and total factor productivity, Journal of Cleaner Production 168: 279-289. Available on the Internet: http://dx.doi.org/10.1016/j.jclepro.2017.09.043

Zhu, Q., Wang, X. 2011. Structural changes of public expenditures in China, Journal of Public Budgeting, Accounting \& Financial Management 23 (4): 569-587. 
Annex A. Jarque-Bera statistics

\begin{tabular}{|c|c|c|c|c|}
\hline Countries & Variables & $\begin{array}{c}\text { Jarque-Bera } \\
\text { statistics } \\
\end{array}$ & Probability & $\begin{array}{c}\text { Test results } \\
\text { (Null hypothesis) }\end{array}$ \\
\hline \multirow{3}{*}{ France } & Real GDP per capita growth & 9.5991 & 0.0082 & Rejected \\
\hline & Log(Real GDP per capita growth) & 4.8465 & 0.0890 & Accepted \\
\hline & Government expenditure & 2.6306 & 0.2684 & Accepted \\
\hline \multirow{3}{*}{ Denmark } & Real GDP per capita growth & 28.2251 & 0.0000 & Rejected \\
\hline & Log(Real GDP per capita growth) & 4.2621 & 0.1187 & Accepted \\
\hline & Government expenditure & 0.9409 & 0.6247 & Accepted \\
\hline \multirow{3}{*}{ Sweden } & Real GDP per capita growth & 13.7453 & 0.0010 & Rejected \\
\hline & Log(Real GDP per capita growth) & 2.9108 & 0.2333 & Accepted \\
\hline & Government expenditure & 4.6036 & 0.1001 & Accepted \\
\hline \multirow{2}{*}{ Greece } & Real GDP per capita growth & 3.1154 & 0.2106 & Accepted \\
\hline & Government expenditure & 5.6812 & 0.0684 & Accepted \\
\hline \multirow{3}{*}{ Hungary } & Real GDP per capita growth & 33.8000 & 0.0000 & Rejected \\
\hline & Log(Real GDP per capita growth) & 6.8315 & 0.0329 & Rejected \\
\hline & Government expenditure & 0.7239 & 0.6963 & Accepted \\
\hline \multirow{3}{*}{ Italy } & Real GDP per capita growth & 10.1683 & 0.0062 & Rejected \\
\hline & Log(Real GDP per capita growth) & 2.9217 & 0.2320 & Accepted \\
\hline & Government expenditure & 2.0109 & 0.3659 & Accepted \\
\hline \multirow{2}{*}{ Poland } & Real GDP per capita growth & 0.4785 & 0.7872 & Accepted \\
\hline & Government expenditure & 0.5684 & 0.7526 & Accepted \\
\hline \multirow{3}{*}{ Czechia } & Real GDP per capita growth & 3.0938 & 0.2129 & Accepted \\
\hline & Government expenditure & 12.8278 & 0.0016 & Rejected \\
\hline & Log(Government expenditure) & 8.2366 & 0.0162 & Rejected \\
\hline \multirow{2}{*}{ Slovakia } & Real GDP per capita growth & 4.5836 & 0.1011 & Accepted \\
\hline & Government expenditure & 1.2856 & 0.5258 & Accepted \\
\hline \multirow{2}{*}{ Cyprus } & Real GDP per capita growth & 3.3495 & 0.1874 & Accepted \\
\hline & Government expenditure & 2.1934 & 0.3340 & Accepted \\
\hline \multirow{3}{*}{ Estonia } & Real GDP per capita growth & 18.4541 & 0.0001 & Rejected \\
\hline & Log(Real GDP per capita growth) & 52.4695 & 0.0000 & Rejected \\
\hline & Government expenditure & 2.5231 & 0.2832 & Accepted \\
\hline \multirow{4}{*}{ Lithuania } & Real GDP per capita growth & 49.1088 & 0.0000 & Rejected \\
\hline & Log(Real GDP per capita growth) & 1.2960 & 0.5231 & Accepted \\
\hline & Government expenditure & 6.2200 & 0.0446 & Rejected \\
\hline & Log(Government expenditure) & 8.1393 & 0.0171 & Rejected \\
\hline
\end{tabular}

Source: authors' calculations based on Eviews v. 8.0.

Note: the level of significance is $5 \%$.

Annex B. Government expenditure by function and its structural change

\begin{tabular}{|l|c|c|c|}
\hline \multicolumn{1}{|c|}{ Government expenditure by function } & 1997 & 2017 & Absolute rate of structural changes, percentage points \\
\hline \multicolumn{3}{|c|}{ France } \\
\hline General public services & 16,2 & 10,6 & $-5,6$ \\
\hline Defence & 4,5 & 3,2 & $-1,3$ \\
\hline Public order and safety & 2,6 & 2,9 & 0,3 \\
\hline Economic affairs & 9,3 & 10,5 & 1,2 \\
\hline Environmental protection & 1,2 & 1,7 & 0,5 \\
\hline
\end{tabular}


JOURNAL OF SECURITY AND SUSTAINABILITY ISSUES

ISSN 2029-7017 print/ISSN 2029-7025 online

\begin{tabular}{|c|c|c|c|}
\hline Housing and community amenities & 1,7 & 1,8 & 0,1 \\
\hline Health & 13,0 & 14,2 & 1,2 \\
\hline Recreation, culture and religion & 1,8 & 2,5 & 0,7 \\
\hline Education & 10,4 & 9,5 & $-0,9$ \\
\hline Social protection & 39,3 & 43,1 & 3,8 \\
\hline Total & 100 & 100 & - \\
\hline \multicolumn{4}{|c|}{ Denmark } \\
\hline General public services & 17,8 & 12,1 & $-5,7$ \\
\hline Defence & 2,9 & 2,3 & $-0,6$ \\
\hline Public order and safety & 1,6 & 1,8 & 0,2 \\
\hline Economic affairs & 6,9 & 6,4 & $-0,5$ \\
\hline Environmental protection & 1,0 & 0,8 & $-0,2$ \\
\hline Housing and community amenities & 1,1 & 0,4 & $-0,7$ \\
\hline Health & 11,7 & 16,4 & 4,7 \\
\hline Recreation, culture and religion & 2,8 & 3,3 & 0,5 \\
\hline Education & 11,5 & 12,7 & 1,2 \\
\hline Social protection & 42,7 & 43,8 & 1,1 \\
\hline Total & 100 & 100 & - \\
\hline \multicolumn{4}{|c|}{ Sweden } \\
\hline General public services & 18,9 & 13,8 & $-5,1$ \\
\hline Defence & 3,9 & 2,4 & $-1,5$ \\
\hline Public order and safety & 2,2 & 2,6 & 0,4 \\
\hline Economic affairs & 7,1 & 8,3 & 1,2 \\
\hline Environmental protection & 0,3 & 0,6 & 0,3 \\
\hline Housing and community amenities & 3,3 & 1,5 & $-1,8$ \\
\hline Health & 10,2 & 14,0 & 3,8 \\
\hline Recreation, culture and religion & 3,0 & 2,2 & $-0,8$ \\
\hline Education & 11,8 & 13,7 & 1,9 \\
\hline Social protection & 39,3 & 40,9 & 1,6 \\
\hline Total & 100 & 100 & - \\
\hline \multicolumn{4}{|c|}{ Greece } \\
\hline General public services & 30,7 & 17,6 & $-13,1$ \\
\hline Defence & 4,3 & 5,3 & 1,0 \\
\hline Public order and safety & 2,1 & 4,5 & 2,4 \\
\hline Economic affairs & 12,2 & 7,6 & $-4,6$ \\
\hline Environmental protection & 0,8 & 2,8 & 2,0 \\
\hline Housing and community amenities & 0,8 & 0,4 & $-0,4$ \\
\hline Health & 11,2 & 11,1 & $-0,1$ \\
\hline Recreation, culture and religion & 1,2 & 1,5 & 0,3 \\
\hline Education & 9,0 & 8,2 & $-0,8$ \\
\hline Social protection & 27,7 & 41,0 & 13,3 \\
\hline Total & 100 & 100 & - \\
\hline \multicolumn{4}{|c|}{ Hungary } \\
\hline General public services & 25,3 & 16,9 & $-8,4$ \\
\hline Defence & 2,8 & 2,1 & $-0,7$ \\
\hline Public order and safety & 3,5 & 5,0 & 1,5 \\
\hline Economic affairs & 10,3 & 15,0 & 4,7 \\
\hline Environmental protection & 1,4 & 1,0 & $-0,4$ \\
\hline Housing and community amenities & 2,4 & 1,7 & $-0,7$ \\
\hline
\end{tabular}




\begin{tabular}{|c|c|c|c|}
\hline Health & 10,6 & 10,2 & $-0,4$ \\
\hline Recreation, culture and religion & 2,5 & 7,4 & 4,9 \\
\hline Education & 10,9 & 10,8 & $-0,1$ \\
\hline Social protection & 30,3 & 29,9 & $-0,4$ \\
\hline Total & 100 & 100 & - \\
\hline \multicolumn{4}{|c|}{ Italy } \\
\hline General public services & 25,7 & 16,8 & $-8,9$ \\
\hline Defence & 2,4 & 2,7 & 0,3 \\
\hline Public order and safety & 4,0 & 3,8 & $-0,2$ \\
\hline Economic affairs & 8,0 & 7,3 & $-0,7$ \\
\hline Environmental protection & 1,4 & 1,9 & 0,5 \\
\hline Housing and community amenities & 1,6 & 1,2 & $-0,4$ \\
\hline Health & 11,0 & 14,0 & 3,0 \\
\hline Recreation, culture and religion & 1,8 & 1,7 & $-0,1$ \\
\hline Education & 9,2 & 7,9 & $-1,3$ \\
\hline Social protection & 34,9 & 42,8 & 7,9 \\
\hline Total & 100 & 100 & - \\
\hline \multicolumn{4}{|c|}{ Poland } \\
\hline General public services & 17,3 & 10,8 & $-6,5$ \\
\hline Defence & 4,8 & 4,1 & $-0,7$ \\
\hline Public order and safety & 5,5 & 5,2 & $-0,3$ \\
\hline Economic affairs & 8,2 & 11,3 & 3,1 \\
\hline Environmental protection & 1,2 & 0,9 & $-0,3$ \\
\hline Housing and community amenities & 3,3 & 1,4 & $-1,9$ \\
\hline Health & 6,6 & 11,4 & 4,8 \\
\hline Recreation, culture and religion & 1,7 & 2,9 & 1,2 \\
\hline Education & 12,6 & 11,9 & $-0,7$ \\
\hline Social protection & 38,9 & 40,0 & 1,1 \\
\hline Total & 100 & 100 & - \\
\hline \multicolumn{4}{|c|}{ Czechia } \\
\hline General public services & 9,0 & 10,0 & 1,0 \\
\hline Defence & 4,2 & 2,1 & $-2,1$ \\
\hline Public order and safety & 4,6 & 4,5 & $-0,1$ \\
\hline Economic affairs & 18,7 & 14,6 & $-4,1$ \\
\hline Environmental protection & 2,5 & 2,1 & $-0,4$ \\
\hline Housing and community amenities & 2,9 & 1,5 & $-1,4$ \\
\hline Health & 15,5 & 19,2 & 3,7 \\
\hline Recreation, culture and religion & 3,2 & 3,4 & 0,2 \\
\hline Education & 11,0 & 11,9 & 0,9 \\
\hline Social protection & 28,5 & 30,7 & 2,2 \\
\hline Total & 100 & 100 & - \\
\hline \multicolumn{4}{|c|}{ Slovakia } \\
\hline General public services & 14,5 & 13,9 & $-0,6$ \\
\hline Defence & 3,0 & 2,4 & $-0,6$ \\
\hline Public order and safety & 7,2 & 5,3 & $-1,9$ \\
\hline Economic affairs & 19,8 & 10,1 & $-9,7$ \\
\hline Environmental protection & 2,6 & 1,8 & $-0,8$ \\
\hline Housing and community amenities & 1,3 & 1,1 & $-0,2$ \\
\hline Health & 12,1 & 17,7 & 5,6 \\
\hline
\end{tabular}




\begin{tabular}{|c|c|c|c|}
\hline Recreation, culture and religion & 2,4 & 2,1 & $-0,3$ \\
\hline Education & 7,1 & 9,4 & 2,3 \\
\hline Social protection & 30,0 & 36,1 & 6,1 \\
\hline Total & 100 & 100 & - \\
\hline \multicolumn{4}{|c|}{ Cyprus } \\
\hline General public services & 21,4 & 19,5 & $-1,9$ \\
\hline Defence & 8,2 & 5,5 & $-2,7$ \\
\hline Public order and safety & 5,3 & 4,5 & $-0,8$ \\
\hline Economic affairs & 11,2 & 6,3 & $-4,9$ \\
\hline Environmental protection & 0,6 & 0,8 & 0,2 \\
\hline Housing and community amenities & 5,6 & 4,2 & $-1,4$ \\
\hline Health & 6,9 & 6,9 & 0,0 \\
\hline Recreation, culture and religion & 2,4 & 2,4 & 0,0 \\
\hline Education & 15,2 & 15,3 & 0,1 \\
\hline Social protection & 23,1 & 34,7 & 11,6 \\
\hline Total & 100 & 100 & - \\
\hline \multicolumn{4}{|c|}{ Estonia } \\
\hline General public services & 11,0 & 9,9 & $-1,1$ \\
\hline Defence & 3,5 & 5,2 & 1,7 \\
\hline Public order and safety & 7,2 & 4,8 & $-2,4$ \\
\hline Economic affairs & 10,8 & 11,0 & 0,2 \\
\hline Environmental protection & 1,8 & 1,9 & 0,1 \\
\hline Housing and community amenities & 1,4 & 0,9 & $-0,5$ \\
\hline Health & 11,7 & 12,8 & 1,1 \\
\hline Recreation, culture and religion & 5,7 & 5,3 & $-0,4$ \\
\hline Education & 18,7 & 14,8 & $-3,9$ \\
\hline Social protection & 28,3 & 33,3 & 5,0 \\
\hline Total & 100 & 100 & - \\
\hline \multicolumn{4}{|c|}{ Lithuania } \\
\hline General public services & 35,0 & 10,6 & $-24,4$ \\
\hline Defence & 3,0 & 5,1 & 2,1 \\
\hline Public order and safety & 4,7 & 4,5 & $-0,2$ \\
\hline Economic affairs & 12,7 & 8,4 & $-4,3$ \\
\hline Environmental protection & 0,3 & 1,3 & 1,0 \\
\hline Housing and community amenities & 1,3 & 1,3 & 0,0 \\
\hline Health & 9,1 & 17,1 & 8,0 \\
\hline Recreation, culture and religion & 2,3 & 3,2 & 0,9 \\
\hline Education & 10,2 & 14,8 & 4,6 \\
\hline Social protection & 21,4 & 33,8 & 12,4 \\
\hline Total & 100 & 100 & - \\
\hline
\end{tabular}

Source: authors' calculations based on Eurostat data (2017a)

Gitana DUDZEVIČIŪTE் is an assoc. professor of General Jonas Žemaitis Military Academy of Lithuania, Department of Strategic Management. Research interests: sustainable development, economic growth and its determinants, defence economics.

Vidmantė GIEDRAITYTE் is an assoc. professor of General Jonas Žemaitis Military Academy of Lithuania, Department of Strategic Management. Research interests: public sector innovation management, pubic governance, administrative regulation. 